\title{
Implementasi Maqashid Syariah dengan Pengembangan Ekonomi Hijau Melalui Urban Farming
}

\author{
Yusvita Nena Arinta \\ Institut Agama Islam Negeri Salatiga \\ Email:nena@iainsalatiga.ac.id
}

\begin{abstract}
The trend of conventional economic in emerging countries raises problems in other sectors with systematic. This results in inconsistencies with the main objectives of carrying out economic activities. Economic goals are not only oriented towards wealth, but also protect the living ecosystem (hifdzu-n-nafsi) and also protect offspring (hifdzu-n-nasli). Fundamental corrections are needed to find new ways of economic development. Green economy as a new way to solve economic problems applying Maqashid Shariah. Green economy through Maqashid Shariah focuses on 3 concepts: 1) the quality of economic growth, 2) environmental efficiency, and 3) social growth. As a paradigm that is able to maintain sustainable ecosystems in achieving social economic growth by supporting welfare improvement. Urban farming is becoming a new path of discovery to develop the prosperity of implementing a green economy in Indonesia. Urban farming is an industrial cycle that produces, processes and sells food and energy to meet the needs of city consumers. All activities are carried out by the method of using and reusing natural resources and urban waste. Besides fulfilling the basic needs of every family that is the basis of a measure of money, urban farming is needed to get money with other household needs. The idea of returning to nature shows that urban agriculture is able to meet economic quality growth targets, save energy and social interaction in accordance with Islamic economic principles.
\end{abstract}

Keywords: Green Economy, Maqashid Syariah, Urban farming.

\begin{abstract}
Abstrak
Tren ekonomi konvensional di negara-negara berkembang menimbulkan masalah di sektor lain dengan sistematis. Ini menghasilkan inkonsistensi dengan tujuan utama melakukan kegiatan ekonomi. Tujuan ekonomi tidak hanya berorientasi pada kekayaan, tetapi juga melindungi ekosistem hidup (hifdzu-n-nafsi) dan juga melindungi keturunan (hifdzu-n-nasli). Koreksi mendasar diperlukan untuk menemukan cara baru pengembangan ekonomi. Ekonomi hijau sebagai cara baru untuk menyelesaikan masalah ekonomi dengan menerapkan Maqashid Syariah. Ekonomi hijau melalui Maqashid Syariah berfokus pada 3 konsep: 1) kualitas pertumbuhan ekonomi, 2) efisiensi lingkungan, dan 3) pertumbuhan sosial. Sebagai paradigma yang mampu mempertahankan ekosistem berkelanjutan dalam
\end{abstract}


mencapai pertumbuhan sosial ekonomi dengan mendukung peningkatan kesejahteraan. Urban farming menjadi jalur penemuan baru untuk mengembangkan kemakmuran menerapkan ekonomi hijau di Indonesia. Urban farming adalah siklus industri yang menghasilkan, mengolah, dan menjual makanan dan energi untuk memenuhi kebutuhan konsumen kota. Semua kegiatan dilakukan dengan metode menggunakan dan menggunakan kembali sumber daya alam dan limbah kota. Selain memenuhi kebutuhan dasar setiap keluarga yang menjadi dasar ukuran uang, pertanian perkotaan diperlukan untuk mendapatkan uang dengan kebutuhan rumah tangga lainnya. Gagasan untuk kembali ke alam menunjukkan bahwa pertanian perkotaan mampu memenuhi target pertumbuhan kualitas ekonomi, menghemat energi dan interaksi sosial sesuai dengan prinsip ekonomi Islam.

Kata Kunci: Ekonomi Hijau, Maqashid Syariah, Pertaniaan Perkotaan.

\section{Pendahuluan}

Perkembangan ekonomi konvensional di negara-negara berkembang, secara fundamental menimbulkan masalah di sektor lain dengan sistematis. Kelangkaan sumber daya, kenaikan harga, anomali iklim, bonus demografi, serta biaya sosial akibat polusi dan limbah menjadi masalah yang muncul pada lini sektor lain (Negin 2017). Tuntutan untuk memenuhi standar hidup layak mendorong laju pertumbuhan ekonomi. Pertumbuhan ekonomi yang diinginkan adalah pertumbuhan ekonomi. Pertumbuhan yang seperti ini adalah perumbuhan yang tidak menyelesaikan kesejahteraan di Indonesia, justru muncul tekanan destruktif pada ekosistem lingkungan. Dengan kata lain perkembangan ekonomi belum mencapai pada tahapan tujuan sustainable. Tujuan ekonomi tidak semata mata hanya berorientasi pada kekayaan, tetapi juga menjaga kelestarian kelangsungan (ekosistem) hidup.

Kegiatan ekonomi yang mampu menggambarkan tujuan sustainable ekonomi adalah kegiatan ekonomi yang berdasarkan maqashid Syariah (Sahroni and Karim 2015). Konsep ekonomi dalam bingkai Maqashid Shariah bertujuan untuk mencapai maslahah dan kemaslahatan bersama, baik kebermanfaatanya baik didunia maupun akherat (Muhajir 2015). Sesuatu dapat dikatakan maslahat jika bisa digunakan dan memiliki keuntungan. Tujuan sustainable ekonomi dapat diinterpretasikan dalam kegiatan ekonomi yang sesuai dengan bentuk Maqashid Syariah yaitu melindungi kekayaan (hifdzu-l-maal) dengan mempertimbangkan persyaratan dan min janibi al-wujud (dari sudut pandang cara mendapatkannya) dan min janibi al-'adam (dari sudut pandang untuk menjaga kekayaan). Kegiatan ekonomi dalam Maqashid Shariah tidak semata semata melindungi kekayaan 
tetapi juga melindungi ekosistem (hifdzu-n-nafsi) dan juga menjaga keturunan (hifdzu-n-nasli).

Tingkatan urgensitas kebutuhan dalam usaha pencapaian pemenuhan sebuah maslahat, yaitu kebutuhan dlaruriyat atau kebutuhan primer, 2) kebutuhan hajiyat atau kebutuhan sekunder, dan 3) kebutuhan tahsinat atau kebutuhan pelengkap (Khallaf 2003). Kebutuhan dlaruriyat merupakan kebutuhan utama yang bersifat harus dipenuhi, jika tidak akan mengakibatkan kehancuran dan kerusakan. Kebutuhan hajiyat adalah kebutuhan yang menimbulkan sebuah kemudahan dan kenyamanan, yang jika tidak terpenuhi mengakibatkan masalah dan kesulitan. Memenuhi kebutuhan hajiyat mengarah pada interaksi sosial dan kehidupan. Untuk kebutuhan yang ketiga adalah kebutuhan tahsinat yang kebutuhan manusia yang mengarah pada martabat, norma dan gaya hidup. Kebutuhan tahsinat menjadikan kondisi manusia agar sesuai dengan tuntutan martabat dan sikap lurus. Kegagalan dalam pemenuhan kebutuhan ini akan mengakibatkan rasa tidak nyaman atau rasa keterasingan.

Didalam hirarki Maqashid Sharia yang harus diutamakan pemenuhan kebutuhanya adalah kebutuhan dlaruriyat sebelum kebutuhan hajjiyah dan tahsinat (Janah and Ghofur 2018). Kegiatan ekonomi dalam tahap pencapaian pemenuhan kebutuhan dlaruriyat, Indonesia masih mengalami kesulitan. Dari data yang dilansir oleh Badan Pusat Statistik menunjukan kemiskinan pangan yang terjadi di Indonesia diperkirakan mencapai 30\% untuk tahun 2017 dan diprediksi meningkat hingga 50\% di tahun 2045. Hal ini merupakan konsekuensi logis yang diterima seiring perkembangan ekonomi yang cukup signifikan dengan diiringi dengan bonus demografi yang sedang dirasakan oleh Indonesia. Kecukupan kebutuhan bahan pokok merupakan salah satu indikator utama pertumbuhan ekonomi di Indonesia yang berati mengisyaratkan kesejahteraan masyarakat Indonesia. Hal ini menjadi tantangan kita bersama, agar persoalan dasar seperti kekurangan pangan tidak pernah terjadi lagi, bahkan seperti krisis pangan yang pernah dialami di Indonesia tahun 2007-2008.

Koreksi mendasar diperlukan untuk menemukan cara baru sebuah pengembangan. Perlu dilakukan sebuah cara baru untuk meningkatkan kesejahteraan masyarakat secara merata, sesuai dengan konsepsi Maqashid Syariah, dengan tujuan memperbaiki kehidupan yang layak bagi umat manusia. Green economy menjadi jalan penemuan baru untuk mengatasi bersama masalah 
kesenjangan kesejahteraan masyarakat. Green economy merupakan konsep yang mendukung tujuan Maqashid Shariah yaitu kesejahteraan manusia, kelestarian lingkungan, dan ekosistem. Hal ini menjadi semakin kuat dengan bukti jargon yang diusung, yaitu pro-growth, pro-poor, pro-job, dan pro-environment (Fauzia 2016). Green economy merupakan aktivitas ekonomi yang selaras dengan tujuan dan prinsip utama yang terdapat dalam Maqashid Shariah, yaitu untuk mencapai kesejahteraan bersama seiring dengan peningkatan hidup manusia dan alam.

Gagasan tentang green economy muncul berawal dari pergeseran gaya hidup yang menyebabkan krisis lingkungan, oleh karena itu konsep green economy digencarkan sebagai upaya untuk tetap mendukung mendukung pembangunan lingkungan (pro-environment), yang berdampak pada berkembangnya sistem ekonomi menuju ekonomi yang ramah lingkungan. Hal ini berkaitan dengan teori $3 \mathrm{P}$ yang di usung oleh El Kington, yang membahas keseimbangan antara Planet (Lingkungan), People (Manusia) dan Profit (Keuntungan Bisnis). Dengan berjalannya green economy, diharapkan tujuan ekonomi berkelanjutan dapat dicapai.

Salah satu kegiatan ekonomi yang mejadi peluang atau potensial termudah dilakukan masyarakat adalah dengan cara urban farming. Urban farming dapat diartikan dengan aktivitas pertanian apa pun seperti termasuk budidaya tanaman pangan, peternakan, kehutanan dan produksi bunga dan tanaman kebun (Averbeke 2007). Urban farming dalam memenuhi kebtuhan pokok harus tetap patuh pada peraturan Maqashid Sharia, karena tujuan dari maqashid sharia itu sendiri adalah Maslahah atau dengan kata lain kesejahteraan untuk bersama adalah puncak dari implementasi Maqashid Shariah (Johnston 2007). Sehingga urban farming menjadi wujud kegiatan green economy dengan tetap berorientasi pada tujuan Maqashid Shariah yaitu maslahah.

Pemenuhan permintaan makanan dan kesenjangan ketersediaan menjadi sebuah urgensi. Sehingga banyak masyarakat kota telah beralih ke urban farming untuk mengisi kesenjangan antara permintaan dan pasokan pangan kota (Umoh 2006). Selain itu urban farming juga bisa dijadikan kegiatan untuk memperoleh pendapatan dengan pemenuhan kebutuhan pangan rumah tangga lainnya. Sehingga tak heran jika praktik pertanian perkotaan terus meningkat dalam beberapa tahun terakhir dengan penyesuaian struktural ekonomi. Oleh karena itu dengan menghidupkan budaya menanam tanaman kebutuhan bahan pangan 
disekitar pekarangan rumah, dapat menjadi terobosan baru menuju kesejahtreraan masayarakat.

Dari uraian diatas, penulis mencoba membuktikan bahwa urban farming mampu menjawab tantangan besar negera ini untuk mewujudkan kesejahteraan Indonesia. Dengan urban farming tujuan ekonomi berkelanjutan dapat terwujud, karena menerapkan sistem maqashid sharia. Dalam menjawab masalah dalam penelitin ini, penulis menggunakan penelitian kualitatif dengan menggunakan pendekatan analisis literature review dengan cara mereduksi data, menyajikan data dalam bentuk narasi hingga menarik kesimpulan.

\section{Maslahah sebagai Tulang Punggung Maqashid Shariah}

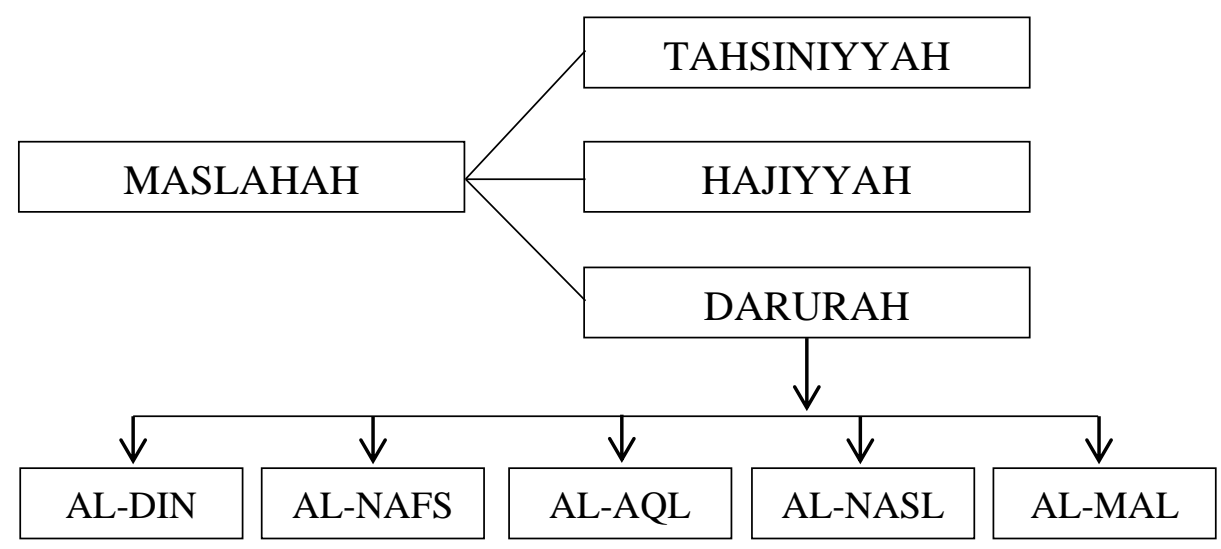

Gambar 1.

\section{Skema Maqashid Shariah}

Didalam Islam selain berpedoman wajib terhadap Alquran, dan sunnah terhadap hadis, Islam mempunyai rujukan dari inductive study (istiqar') yang dihasilkan dari teks-teks hukum dan hukum-hukum yang diturunkan hingga kebijaksanaan hukum. Studi inductive ini merujuk dan mengarah pada benang merah bahwa niat dan tujuan diberlakukanya syariat kepada umat manusia demi tujuannya yaitu maslahah dan kemaslahatan bersama, baik kebermanfaatanya di dunia dan akherat (Muhajir 2015). Sesuatu dapat dikatakan maslahat jika bisa digunakan dan memiliki keuntungan. Keuntungan di maqashid sharia harus bisa diinterpretasikan dalam 5 prinsip tujuan, yang mengarah pada temuan dalam 
Kulliyat al-Khamsah (Muhajir 2015; Sahroni and Karim 2015). Imam Al Ghazali menyatakan ada lima yaitu: 1) hifdzu-d-din, melindungi agama, 2) hifdzu-n-nafsi, melindungi nyawa, 3) hifdzu-l'aql, melindungi akal, 4) hifdzu-l-maal, melindungi harta, dan 5) hifdzu-n-nasli, melindungi keturunan (Bedoui 2012).

Istilah kata maqashid diambil dari istilah bahasa arab yang mempunyai arti tujuan, sasaran, prinsip dan maksud (Kasri and Ahmed 2015). Sedangkan istilah kata shariah dapat didefinisikan sebagai tercapainya tujuan dan sasaran demi legislasi peraturan Islam atau dalam istilah tujuan hukum Islam (Abdul Aziz and Mohamad 2013). Maqashid Shariah secara terminologi dapat diartikan dengan maksud Allah selaku pembuat shariah untuk memberikan kemaslahatan (maslahah) kepada manusia, yaitu dengan terpenuhinya kebutuhan-kebutuhan dlaruriyah, hajjiyah, dan tahsiniyah agar manusia bisa hidup dalam kebaikan dan dapat menjadi hamba Allah yang baik (Fauzia 2016). Para Ulama terdahulu menyepakati bahwa shariah diturunkan untuk membangun kemaslahatan manusia di dunia dan akhirat. Dan shariah diturunkan untuk dilaksanakan sesuai dengan maqashid-nya agar kehidupan yang adil dapat ditegakkan dan kesejahteraan sosial dapat diwujudkan. Kemaslahatan adalah segala sesuatu yang bermanfaat bagi manusia, yang dapat diraih oleh manusia dengancara memperolehnya maupun dengan cara menghindarinya. Hakikat perintah dan larangan syara' pada dasarnya untuk mewujudkan tujuan syariat yang dikembalikan pada suatu kaidah yaitu jalb al-masalih wa dar'u al-mafasid (merealisasikan kemaslahatan dan menolak kerusakan).

Berkenaan dengan klasifikasi maqashid al-syari'ah, Maslahat ini terbagi kepada tiga bagian penting yaitu dharuriyyat (primer), hajiyyat (sekunder) dan tahsiniyat (tersier) (As-Syatibi 1997). Al-dharuriyyat, yaitu sesuatu yang mesti ada demi terwujudnya kemaslahatan agama dan dunia. Apabila hal ini tidak ada, maka akan menimbulkan kerusakan bahkan hilangnya hidup dan kehidupan seperti makan, minum, shalat, puasa dan ibadah-ibadah lainnya. Termasuk maslahat atau maqashid dharuriyyat ini ada lima, yaitu: agama (al-din), jiwa (al-nafs), keturunan (an-nasl), harta (al-mal) dan akal (al-aql). Cara untuk menjaga yang lima tadi dapat ditempuh dengan dua cara yaitu, pertama, dari segi adanya (min nahiyyati alwujud) yaitu dengan cara menjaga dan memelihara hal-hal yang dapat melanggengkan keberadaannya. Kedua, dari segi tidak ada (min nahiyyati aladam) yaitu dengan cara mencegah hal-hal yang menyebabkan ketiadaannya. Al- 
hajiyat, yaitu sesuatu yang sebaiknya ada agar dalam melaksanakannya leluasa dan terhindar dari kesulitan. Jika sesuatu ini tidak ada, maka ia tidak akan menimbulkan kerusakan atau kematian hanya saja akan mengakibatkan masyaqqah (kesempitan). Misalnya, dalam masalah ibadah adalah adanya rukhsah; shalat jama dan qashar bagi musafir. Dalam muamalah, syariat membolehkan jual beli yang merupakan pengecualian dari kaidah umum jual beli, seperti salam, ijarah, dan lainnya. Al-tahsiniyat, yaitu sesuatu yang sebaiknya ada demi sesuainya dengan akhlak yang baik atau dengan adat. Jika sesuatu ini tidak ada, maka tidak akan menimbulkan kerusakan atau jika sesuatu itu hilang tidak akan menimbulkan masyaqqah dalam melaksanakannya, hanya saja dinilai tidak pantas dan tidak layak menurut ukuran tata krama dan kesopanan. Di antara contohnya adalah thaharah, menutup aurat dengan pakaian yang bersih dan bagus, larangan israf, cara makan dan minum yang baik. Kondisi ini merupakan kondisi pelengkap hidup manusia, sehingga manusia merasakan kenyamanan hidup.

Tujuan maqashid dapat diklasifikasikan menjadi tiga tujuan besar (Mohammed and Razak 2008) yang terdiri dari pendidikan individu, menciptakan keadilan dan menutamakan kesejahteraan. Indikator yang terdapat dalam klasifikasi tujuan Maqasid al-Shari'ah dimaksdukan untuk pencapaian bersama antara individu dan publik. Hal Ini dijadikan dasar untuk pengembangan peraturan dengan memahami pedoman nilai nilai yang terdapat dalam sistem ekonomi (Abdullah 2012). Maqashisd sharia perlu diterapkan dalam praktik kegiatan ekonomi karena dapat meminimalisir ataupun mencegah akibat negatif dari efek ekonomi, psikologi negatif, dan peluang yang menimbulkan spekulasi (Rafikov, I. and Saiti 2017).

Tujuan maqashid sharia yaitu tercapainya sebuah mashlahah. Sedangkan maslahah dapat tercapai jika memenuhi kriteria tertibnya kehidupan dunia demi tercapainya kehidupan akhirat. Dengan begitu mashlahah mempunyai arti yang universal, berlaku untuk umum dan abadi atas seluruh manusia dan dalam segala keadaan. Tulang punggung dari sebuah maslahah adalah sebuah kesejahteraan (Johnston 2007). Istilah kesejahteraan dapat diartikan sebagai suatu alat untuk mengarahkan masyarakat, salah satunya dengan komunitas bisnis, untuk beradaptasi terhadap berbagai perubahan (Johnston 2007). Dalam kesejahteraan sosial (Choudhury 1999) dijelaskan bahwa fungsi dari kesejahteraan itu sendiri sebagai fungsi yang bersifat netral atau tidak memihak yang bisa menjelaskan dan 
mengukur tingkat kesatuan hubungan antara variabel yang satu dengan variabel yang lain. Kesejahteraan juga dapat diartikan sebagai pengalaman unik yang mengandung nilai nilai yang dilihami oleh konteks sosial dan budaya (Andreoni and Galmarini 2016). Dalam perubahan global, dimana kehadiran industri kecil, harus tetap mencapai nilai-nilai yang terdapat kesejahteraan dalam segala ruang lingkup sosial ekonomi, politik, ilmu pengetahuan dan teknologi (Choudhury 1999). Oleh karena itu, kegiatan urban farming harus sesuai dan mencapai tujuan kesejahteraan sosial Islam.

\section{Green Economy dalam Maqashid Shariah}

Kegiatan ekonomi berlandaskan maqashid sharia adalah kegiatan ekonomi dengan menempatkan pemenuhan kebutuhan dasar sebagai piroritas utama agar tetap terwujudnya dan terpelihara lima pokok maslahat, yaitu pemeliharaan agama, jiwa, keturunan, akal, dan harta (Rahma and Makhlani 2013). Dalam kegiatan ekonomi berdasarkan maqashid sharia berbeda dengan kegiatan ekonomi yang lainya. Dalam kegiatan ekonomi berdasarkan maqashid sharia mengandung unsur moral dan nilai ibadah. Sedangkan kebalikan dari maqashis shariah sendiri adalah mafsadah. Kegiatan ekonomi yang berdasarkan maqashid sharia adalah melindungi kekayaan (hifdzu-l-maal) dengan melakukan 2 tindakan yaitu min janibi al-wujud (fokus pada proses bagaimana cara mendapatkanya) dan min janibi al-'adam (fokus pada aspek cara pengelolaan kekayaan). Terdapat dua tipe dalam tujuan ekonomi syariah yang dapat di jelaskan dalam penelitian ini, yaitu maqashid 'ammah dan maqashid kashshah (Sahroni and Karim 2015).

Yusuf Qardhawi menyatakan dalam Ri'ayah al-Bi'ah fi Syari'ah al-Islam, bahwa dalam memelihara lingkungan sama seperti dengan menjaga lima tujuan dasar Islam (maqashid al-syari' ah). Hal ini dikarenakan kelima focus tujuan dasar tersebut bisa menjelaskan jika lingkungan dan alam semesta mendukungnya. Dengan demikian, melestarikan lingkungan mempunyai hukum yang sama dengan maqashid al-syari'ah (Al-Qardhawi 2001). Dan ekonomi islam merupakan satu satunya konsep ekonomi yang mengandung pedoman nilai-nilai maqashid syari'ah adalah Ekonomi Islam. Semakin menjadi nyata bahwa Ekonomi Hijau merupakan refleksi pada Ekonomi Islam. Kesamaan substansi antara konsep Green Economy dan maqashid al-syari'ah yang sangat menekankan pada aspek kemaslahatan, mengacu kepada pemeliharaan terhadap lima hal tujuan dasar (al- 
dharuriyyat). Pertama, pemeliharaan agama (hifzhu al-din). Semua cendekiawan muslim sepakat bahwa agamalah yang harus diutamakan setiap kali menetapkan hukum. Agama yang dimaksud tentunya agama Islam itu sendiri. Alasan mengapa agama Islam itu harus dipelihara, karena Agama yang paling hijau atau paling memperhatikan lingkungan bumi ini adalah Islam.

Dalam bukunya yang berjudul "Green Deen", Ibrahim Abdul Matin, seorang muslim yang menjadi kewarganegaraan Amerika Serikat, menyatakan bahwa wajib di antara umat Islam dan siapa pun yang peduli untuk menyelamatkan bumi. Lensa ini mencakup berbagai prinsip-prinsip keesaan ciptaan, kepengurusan planet ini dan kepercayaan yang menyertainya, keadilan, keseimbangan, dan tanda-tanda Tuhan. Semua prinsip ini menunjukkan rahasia yang sama: bahwa Islam mengajarkan cinta yang mendalam kepada planet ini, karena mencintai planet ini berarti mencintai diri kita sendiri dan mencintai Pencipta kita. Hal ini juga dikuatkan dengan sabda Rasulullah, "Ju' ilat al-ardhu kulluha masjidan", yang berarti bahwa seluruh bumi dijadikan masjid. Dalam pandangan Ibrahim Abdul Matin, hadits tersebut tidak hanya menerangkan bahwa kita boleh mengerjakan shalat di tempat mana pun yang bersih dan suci, namun ada pesan tersirat untuk memelihara alam. Dengan kata lain, memelihara agama Islam merupakan refleksi dari pemeliharaan lingkungan itu sendiri.

Kedua, pemeliharaan jiwa (hifzhu al-nafs), yaitu pemeliharaan hak untuk hidup secara terhormat dan memelihara jiwa agar terhindar dari tindakan penganiayaan, berupa pembunuhan, pemotongan anggota badan maupun tindakan melukai. Islam tentunya sangat menjunjung tinggi jiwa manusia, sehingga dalam kegiatan apapun termasuk ekonomi, keselamatan jiwa perlu diutamakan. Dari definisi UNEP, Ekonomi Hijau tak hanya berhubungan dengan lingkungan namun juga kesejahteraan sosial masyarakat. Di sini sebenarnya ada timbal balik antara jiwa manusia dan lingkungan itu sendiri. Sebagai contoh, pencemaran lingkungan yang diakibatkan oleh beberapa industri sering kali membahayakan jiwa manusia. Perusahaan yang mengaplikasikan Green Economy tidak hanya mengandalkan green washing saja sebagai penghapus dosa atau citra buruknya di masyarakat, tetapi juga akan melakukan tindakan preventif karena benar-benar merasa bertanggung jawab atas jiwa setiap manusia. Bidang pertanian dan perikanan yang menjadi sektor yang memegang peranan penting dalam membentuk Ekonomi Hijau, menjadi sumber pangan untuk diproduksi. Sektor 
pertanian dan perikanan ini juga menyerap sebagian besar tenaga kerja dan menjadi sumber pendapatan, baik secara rata-rata di suatu negara maupun secara global. Dengan demikian, pengelolaan pertanian yang berkelanjutan (sustainable farming) akan membentuk atau berperan besar dalam pembentukan Ekonomi Hijau di suatu negara. Hal lain yang lebih penting lagi, adalah bahwa komposisi kemiskinan dalam sektor pertanian juga sangat besar, sehingga pembentukan sustainable farming akan menjadi peluang baru sebagai sarana menurunkan kemiskinan di sektor pertanian. Pendapatan perkapita suatu negara yang naik dan harus dibarengi dengan berkurangnya kemiskinan (secara riil) dan meratanya distribusi pendapatan dengan baik yang didengungkan dalam konsep Green Economy sesunguhnya menjadi jalan bagi penjagaan jiwa seorang manusia untuk tetap hidup dengan layak. Agama Islam yang kaffah ini telah melarang segala bentuk perusakan terhadap alam sekitar, baik pengerusakan secara langsung maupun tidak langsung. Allah telah melarang perbuatan merusak lingkungan hidup karena bisa membahayakan kehidupan manusia di muka bumi. Karena bumi yang kita tempati ini adalah milik-Nya dan kita hanya diamanahkan untuk menempatinya sampai pada batas waktu yang telah Allah tetapkan. Oleh karena itu, manusia tidak boleh semena-mena mengeksplorasi alam tanpa memikirkan akibat yang muncul. Hal ini sesungguhnya sejalan dengan konsep Green Economy. Kerusakan alam dan lingkungan hidup yang kita saksikan sekarang ini merupakan akibat dari perbuatan umat manusia. Allah menyebutkan hal tersebut dalam firman-Nya, "Telah nampak kerusakan di darat dan di laut disebabkan karena perbuatan tangan manusia, supaya Allah merasakan kepada mereka sebahagian dari (akibat) perbuatan mereka, agar mereka kembali (ke jalan yang benar)". (QS. ar-Rum:41). Salah satu bukti bahwa Islam sangat memperhatikan lingkungan alam sekitar adalah perintah Nabi untuk menyingkirkan gangguan dari jalan yang beliau jadikan sebagai salah satu cabang keimanan, perintah beliau untuk menanam pohon walaupun esok hari kiamat. Dalam hal ini pemerintah berhak memerintahkan rakyat untuk menanam pohon.

Ketiga, pemeliharaan akal (hifzhu al-aql). Lingkungan yang sehat sering kali membantu manusia untuk berpikir jernih dan positif. Di sinilah industri yang go green berperan dalam menciptakan suasana yang tidak mengganggu akal pikiran masyarakat. Pemeliharaan akal ini juga seringkali diterapkan dengan berbagai cara seperti penyediaan beasiswa untuk pelajar-pelajar berprestasi, mengadakan 
kompetisi dalam pengembangan potensi atau juga menerima company visit yang dilakukan oleh pelajar pada pabrik-pabrik untuk research.

Keempat, pemeliharaan keturunan (hifzhu al-nasl). Penggunaan sumber daya yang efisien dalam konsep Green Economy sejalan dengan maqashid al-syariah. Penggunaan sumber daya yang hemat erat kaitannya dengan pemeliharaan keturunan, dimana keefisienan penggunaan sumber daya memberikan lahan bagi generasi yang akan datang untuk dapat memanfaatkan sumber daya. Perusahaan industri maupun pelaku ekonomi lainnya seharusnya selalu memikirkan dampak jangka panjang atas segala perbuatannya. Praktik-praktik pemanfaatan alam dan lingkungan hidup yang secara nyata mengancam keberlangsungan jiwa dan generasi manusia, secara etis tidak boleh dibiarkan. Kaidah Ushul Fiqih telah memberikan kerangka konseptual: dar'u al-mafasid muqaddam 'ala al-jalb almashalih (menolak bahaya lebih diutamakan daripada meraih kemaslahatan). Pengertian menjaga diri (hifzh al-nafs) bukan hanya diletakkan pada konteks masa kini, tetapi juga masa yang akan dijalani oleh generasi mendatang. Oleh karena itu, faktor mashlahat (kemaslahatan) dan mafsadat (kerusakan) tersebut haruslah mempertimbangkan nasib kehidupan generasi mendatang, karena Islam melarang umat manusia meninggalkan generasi yang lemah (QS. al-Nisa': 9), di mana kelemahan mereka disebabkan oleh perbuatan kita di masa sekarang.

Kelima, pemeliharaan harta (hifzhu al-maal). Ekonomi yang sehat selalu menghasilkan profit dengan jalan yang benar, serta mencegah kegiatan ekonomi yang dapat menodai harta pribadi maupun harta orang lain seperti tadlis, gharar, riba dan lainnya. Dalam urutan kulliyah khamsah, mayoritas ulama sepakat menempatkan harta di urutan terakhir. Hal ini berbeda dengan konsep triple bottom line yang menempatkan profit pada urutan pertama. Di sinilah perbedaan konsep Green Economy pada platform ekonomi konvensional dengan konsep maqashid syari'ah pada Ekonomi Islam. Jika ekonomi konvensional bersifat profit oriented, maka Ekonomi Islam bersifat falah oriented.

Pertumbuhan ekonomi mengakibatkan masalah penting pada sektor lain, yaitu pada keberlanjutan ekosistem yaitu kerusakan lingkungan . Kerusakan lingkungan yang biasanya disebabkan oleh kegiatan manusia, termasuk didalamnya aktivitas ekonomi,. Hal ini tentunya tidak sesuai dengan tujuan ekonomi yang sesuai dengan maqahsid shariah. Kerusakan lingkungan akibat ulah manusia ternyata sudah digambarkan dalam al Qur' an sebagai penghancuran keseimbangan. Hal ini sesuai 
dengan yang dinyatakan oleh (Shihab 2003) dalam menafsir surat al Qur'an ar Rum (30) ayat 41 yang menyatakan bahwa makna dari fasaad merupakan sesuatu yang tidak seimbang atau kebalikan dari ash-shalaah yang berarti berguna dan bermanfaat. Dengan demikian ayat tersebut menggambarkan eksplorasi aktivitas manusia yang menyebabkan ketidakseimbangan, kerusakan dan kurangnya kebermanfaatan di darat dan di laut, yang mengacu pada sebuah keseimbangan lingkungan yang bermasalah. Fasaad dilakukan oleh manusia dan akan menyebabkan penyiksaan terhadap manusia. Pertumbuhan ekonomi yang pesat menimbulkan masalah semakin banyak kerusakan yang menerka lingkungan, akan membawa efek buruk manusia, karena Allah menciptakan semua hal yang saling berhubungan dan saling seimbang.

Diperlukan terobosan baru sebuah pengembangan akan kegiatan ekonomi, atas koreksi mendasar dari sebuah kerusakan akibat kegiatan ekonomi. Dalam hal ini diperlukan cara baru kegiatan ekonomi yang mampu mengembalikan kerusakan lingkungan, mengembalikan harmonisasi dan keseimbangan antara alam, manusia, dan ekonomi. Tentunya arah baru dari sebuah terobosan kegiatan ekonomi selain memberikan kesejahteraan bersama juga tetap menjaga kelestarian lingkungan. Green economy adalah sistem perekonomian dengan rendah karbon (low carbon economy) atau tidak menimbulkan emisi dan polusi lingkungan, terjadi sebuah efisiensi sumber daya (resource efficient), dan menciptakan keadilan sosial yang berhubungan dengan income per capita dan kemiskinan (socially inclusive) (UNEP 2008).

Gagasan konsep green economy sebagai terobosan baru dalam kegiatan ekonomi yang mempunyai tujuanm meningkatkan kesejahteraan manusia dan pertumbuhan ekonomi yang beriringan dengan pembangunan manusia dan lingkungan hidup. Hal ini didukung oleh beberapa peneltian. Diantaranya adalah penelitian kelestarian lingkungan dalam perspektif Islam yang dilakukan oleh Muhammad Ramzan Akhtar. Dalam penelitianya yang konsen terhadap keseimbangan lingkungan dengan menggunakan pendekatan Islami ini mengungkap mengenai pandangan Islam dan pandangan negara terhadap lingkungan hidup. Peneliti yang merupakan seorang professor pada sebuah perguruan tinggi School of Economic di International Islamic University, Islamabad, Pakistan menyatakan bahwa di negara bagian barat sedang berkembang suatu disiplin ilmu yang menjadi sebuah trend yaitu ilmu ekonomi 
lingkungan hidup (Akhtar 1996). Dalam ilmu ekonomi lingkungan tersebut menyediakan solusi atas berbagai persoalan yang muncul dengan kerusakan bumi. Disiplin ilmu tersebut mampu menjadi solusi dengan menghasilkan beberapa kebijakan-kebijakan ekonomi, yang bertujuan dengan pelestarian lingkungan hidup.

Kajian tentang green economy juga dilakukan oleh Negin Vaghefi, Chamhuri Siwar, Sarah Aziz, dan Abdul Ghani Aziz yang berasal dari Institute for Environment and Development (LESTARI), University Kebangsaan Malaysia. Penelitian ini melakukan kajian khusus terhadap pembangunan di Negara Islam yang membangun sistem perekonomian dengan mendukung pertumbuhan dan pembangunan, dalam hal kemanfaatan resources dari alam, membuka lapangan kerja, peningkatan kesejahteraan manusia, memberantas kemiskinan, dan kesetaraan kesenjangan (Negin 2017). Oleh karena itu pembangunan ekonomi negara sangat membutuhkan ekonomi hijau. Permasalahan utama yang dihadapi ketika menerapkan sistem green economy di sebagian besar negara Islam adalah belum adanya keunggulan manajemen yang baik, termasuk pemberantasan kemiskinan, kelangkaan sumber daya dan kelangkaan hasil pertanian atau batas persediaan bahan pangan. Pemerintah sebagai pusat pemangku kebijakan haruslah mengarahkan kebijakan yang mendukung terlaksananya green economy. Termasuk sistem reward bagi siapa saja yang menerapkan green economy.

\section{Urban Farming untuk Kesejahteraan Indonesia}

Salah satu penerapan aktivitas green economy adalah dengan urban farming. Urban farming adalah optimalisasi pemanfaatan lahan kosong dan terbuka hijau di sekitar pekarangan rumah warga perkotaan agar menjadi lahan hijau yang produktif. Urban farming merupakan metode terobosan baru yang digunakan untuk menghadapi emerging economy. Dengan kata lain urban farming memberikan tawaran peluang sosial dan ekonomi pada masyarakat perkotaan (Thomaier 2014). Urban farming mampu menyadarkan bagaimana perekonomian dan lingkungan dengan system pertanian dapat terbentuk.

Budaya urban farming selain menerapkan prinsip maqashid syariah juga menerapkan menerapkan prinsip budaya hidup sehat yaitu konsep back to nature dan grow your own food yaitu menanam sendiri kebutuhan tanaman yang bisa dikonsumsi di pekarangan rumah maupun lahan-lahan sekitar yang belum 
dimanfaatkan. Hasil panen dari urban farming lebih menyehatkan karena sepenuhnya menerapkan sistem penanaman organik, yang tidak menggunakan pupuk kimia dan pestisida sintesis.

Council on Agriculture, Science and Technology (CAST) menyatakan Pertanian Perkotaan mencakup aspek kesehatan lingkungan, remediasi, dan rekreasi (Butler and Moronek 2002). Di berbagai kota, Pertanian Perkotaan menjadi pendukung aspek keindahan kota dan kelayakan penggunaan tata ruang yang berkelanjutan.

Peran serta pemerintah juga dibutuhkan sebagai pemangku arah kebiajakan yang mendukung dan memperkuat green economy melalui urban farming. Pelaku urban farming baik melalui komunitas, organisasi organisasi juga menjadi feedback untuk pemerintah dalam hal pembuatan kebijakan lokal dan perencanaan tindakan serta untuk mendorong pendidikan petani dan inovasi dalam sistem pertanian perkotaan untuk membuat ini lebih aman dan lebih produktif. Hal yang perlu menjadi perhatian pemerintah adalah melalui kegiatan yang meningkatkan keahlian dalam urban farming seperti pelatihan (partisipatif) dan penelitian tindakan dengan kelompok-kelompok urban farming untuk mengembangkan sistem urban farming yang aman dan layak (training lapangan petani, pengembangan teknologi partisipatif). Pelaku urban farming ini dapat mengembangkan usahanya melalui dukungan dalam pengembangan usaha mikro (misal: Pemrosesan berbasis rumah) dan pemasaran (kontrol kualitas, label sendiri, pasar petani) dan penguatan hubungan antara berbagai kelompok tani dan pemangku kepentingan lainnya (pendekatan rantai nilai). Ini juga membutuhkan keterlibatan yang lebih kuat dari sektor swasta (bank, lembaga kredit) untuk membiayai investasi dalam pengembangan pertanian dan perusahaan. Hal lain yang tak kalah pentingnya adalah pengembangan cara inovatif untuk meningkatkan akses petani ke lahan kota yang kosong dan meningkatkan keamanan mereka atas hasil produksi perlu perhatian lebih lanjut.

\section{Analisis SWOT Urban Farming}

\section{Strenght}

Pertama, produksi bahan makanan sendiri dalam kota dapat memperpendek proses distribusi pangan dan dapat mengurangi harga jual sehingga meningkatkan daya beli masyarakat (akses pangan) (World Bank, 2013); kedua, kesejahteraan 
sosial yang merata, akibat interaksi soaisal yang semakin tinggi; ketiga, urban farming dapat meningkatkan ketahanan pangan melalui perbaikan ketersediaan dan mengurangi pengeluaran pangan rumah tangga (Kurniasih, 2015); keempat, Banyak metode yang dapat dilakukan melalui sektor pertanian dan non pertanian; kelima, keuntungan letak geografis Indonesia sebagai negara agraris; keenam, berkontribusi untuk mendaur ulang limbah menjadi sumber daya produktif; dan ketujuh, dampak positif pada penghijauan kota, peningkatan iklim mikro perkotaan (pemecah angin, pengurangan debu, naungan) dan pemeliharaan keanekaragaman hayati.

\section{Weakness}

Pertama, resiko urban farming terkait dengan kesehatan manusia apabila tidak terdapat pengelolaan yang tepat dan tindakan pencegahan yang diterapkan akan menimbulkan resiko pada kesehatan lingkungan. Seperti terkontaminasi virus hewan; dan kedua, mencemari sumber air lokal jika input pupuk kimia dan pestisida yang terlalu tinggi digunakan. Debit air limbah dari peternakan unggas intensif misalnya dapat tinggi mikroorganisme dan dapat mencemari persediaan air minum.

\section{Oppoturnities}

Pertama, meningkatkan landscape wisata edukasi yang dapat menjadi potensial kunjungan daerah wisata; kedua, merangsang pengembangan usaha mikro untuk produksi input pertanian yang diperlukan (pakan ternak, kompos, dan cacing tanah), pemrosesan, pengemasan dan pemasaran produk dan rendering layanan lainnya (layanan kesehatan hewan, pembukuan, transportasi); ketiga, meningkatkan akses ekonomi rumah tangga melalui pendapatan rumah tangga. Menurut FAO (2011), selain untuk mendukung ketahanan pangan di perkotaan, urban farming juga bertujuan untuk meningkatkan pendapatan pengelolanya; keempat, interaksi dengan alam, back to nature, budaya untuk konsumsi makanan dari sumber organic yanhg sehat; kelima, peran serta dukungan pemrintah dalam membuat kebijakan untuk meningkatkan green ekonomi melalui urban farming; keenam, selain interaksi dengan alam juga terdapat interaksi sosial. Interaksi dengan sesame manusia untuk berkomitmen menjaga kelestarian lingkungan, ketujuh, peluang pengembangan rantai pasaokan makanan berkelanjutan; dan kedelapan, pasarberbasais modal alam yang baru. 


\section{Threats}

Persaingan yang ketat untuk tanah, pertanian perkotaan sering didorong kembali ke daerah marginal dalam kota seperti lahan basah dan lereng bukit, di mana ia dapat merusak ekosistem yang rapuh jika tidak dipandu dengan benar.

\section{Pengaruh Urban Farming pada Green Economy}

Menerapkan prinsip ekonomi untuk menyelesaikan tantangan dalam hal distribusi sumber daya langka ke seluruh pengguna yang saling berkompetitif. Munculnya isu tentang pembangunan ekonomi berkelanjutan, yang didalamnya terdapat urgensi kebutuhan akan sistem ekonomi hijau berkelanjutan, memberikan peluang nyata yang besar untuk perlunya melakukan koreksi terhadap sistem ekonomi. Koreksi yang dimaskud adalah tinjauan mendasar terhadapa tujuan pertumbuhan ekonomi, yang biasanya hanya pada tujuan prioritas lebih tinggi dilakukan arah target barau pada hal yang kurang penting seperti pelestarian lingkungan dan keadilan sosial. Ekonomi hijau merupakan sasaran baru dengan sorotan evaluasi pada kesalahan sistem ekonomi arus utama dalam kehidupan tranformasi global seperti saat ini (Kennet 2008).

Ekonomi hijau menjadi paradigma baru yang dapat melindungi serta melestarikan ekosistem untuk mengikuti trend baru pertumbuhan ekonomi yang mampu meminimalisir kemiskinan (DESA 2011). Paradigma baru ini menyadari bahwa kaum miskin lebih menderita dari kerusakan lingkungan. Oleh karena itu kehadiran ekonomi hijau bergerak untuk mengelola kemiskinan, anomali iklim dengan menciptakan sistem ekonomi yang mengutamakan prinsip ramah lingkungan dan mampu menciptakan keadilan sosial. Dalam melakukan kegiatan ekonomi lainya seperti investasi, produksi, distribusi, dan konsumsi, sistem ini selain ramah lingkungan, tetapi juga dapat menyediakan produk dan layanan yang dapat meningkatkan kualitas daya dukung lingkungan (UNEP 2008). Dalam setiap kegiatan ekonomi, green ekonomi tidak hanya berperan pada tujuan untuk mencapai sasaran ekonomi saja, tetapi sistem ekonomi hijau juga mencakup berbagai pertimbangan ekologis. Sistem ini juga mengakomodir faktor eksternal yang biasanya diacuhkan oleh sistem ekonomi konvensional (Saumya 2007). Ekonomi hijau menekankan focus pada tiga prinsip dasar: 1) pertumbuhan ekonomi, 2) efisiensi, dan 3) kualitas pertumbuhan ekonomi (Regionomica 2012). 
Pertumbuhan tetap menduduki fokus utama dalam implementasi dan pengembangan green economy.

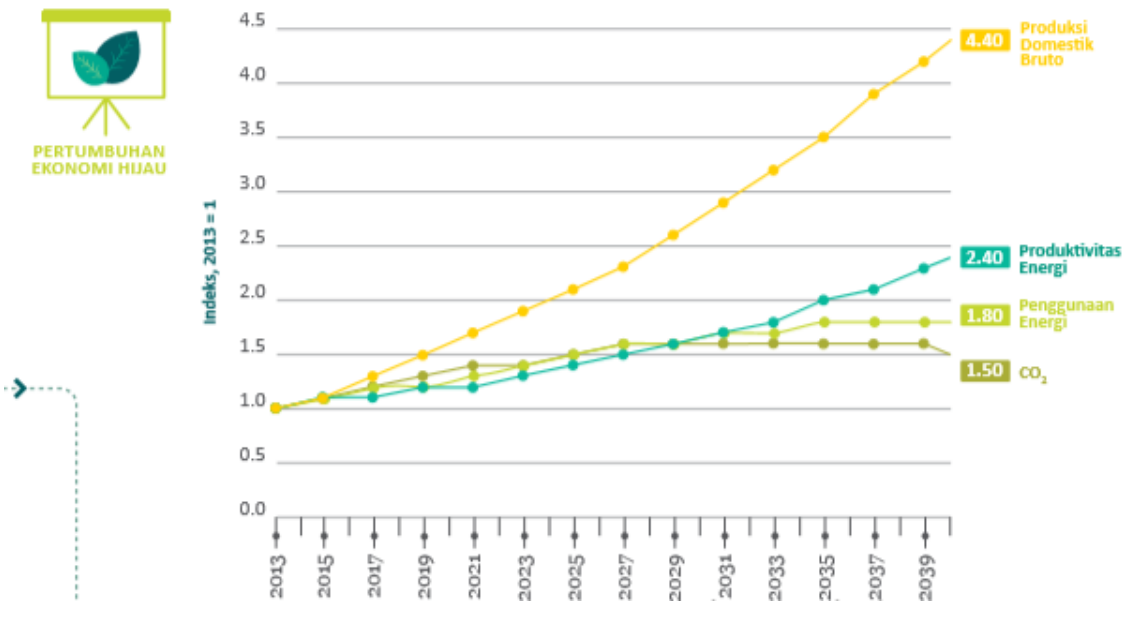

\section{Gambar 2.}

\section{Pertumbuhan Ekonomi Hijau}

Sumber: BPS, 2015

Hal ini dapat digambarkan sebagai alat yang digunakan untuk mencapaian berbagai tujuan dalam fokus ekonomi hijau seperti upaya meminimalisir kemiskinan dan penciptaan kesejahteraan bersama. Namun, perlu upaya maksimal dalam mengoreksi kegiatan ekonomi untuk mencapai pertumbuhan yang diharapkan. Saat ini, pertumbuhan ekonomi difokuskan pada pengukuran kuantitas di pasar. Praktik ekonomi yang diterapkan oleh banyak negara maju menjadi sorotan utama karena terbukti mempunyai dampak yang serius yaitu menyebabkan kerusakan ekosistem lingkungan. Solusi yang muncul untuk mengatasi masalah tersebut adalah dengan memperbaiki lingkungan dengan memanfaatkan sebagian dari pembangunan ekonomi. 


\section{Kesimpulan}

Indonesia dengan sumber daya yang terbarukan saat ini masih terus berupaya untuk mencapai pertumbuhan ekonomi dengan tujuan masalahah sesuai dengan yang dikandung dalam maqashid sharia. Salah satu upaya yang dilakukan adalah terus mencoba mencari sumber daya terbarukan walaupun saat ini masih mengandalkan masih sistem energi yang tidak berkelanjutan. Jika melihat dampak jangka panjang yang dirasakan adalah sangat besar bagi pembangunan nasional. Oleh karena itu perlu dilakukan perubahan mendasar untuk menerapkan ekonomi hijau di Indonesia. Pertumbuhan itu peelu dorongan dari kita semua. Penerapan urban farming adalah salah satu aspek kunci dalam menerapkan ekonomi hijau. Urban farming mencoba menawarkan beberapa manfaat nyata (kelestarian lingkungan, peningkatan pendapatan) dan tidak berwujud (interaksi sosial) yang tetap mematuhi prinsip prinsp Maqashid Shariah dalam kegiatan ekonominya untuk memenuhi prinsip dasar ekonomi hijau. Manfaat yang dapat dirasakan dari urban farming seperti menciptakan pasar pekerjaan dengan ramah lingkungan, mengurangi polusi dan limbah, meningkatkan kebutuhan pangan pokok dan meningkatkan kualitas sumber pangan pokok, meningkatkan pendapatan perorangan, interaksi sosial yang semakin kiuat. Dapat disimpulkan bahwa pemanfaatan urban farming dapat meningkatkan pertumbuhan ekonomi dan efisiensi lingkungan. Pemanfaatan urban farming terbarukan juga cocok dengan maqashid syariah dalam praktik ekonomi Islam. Tidak hanya itu adalah bentuk hifdzu-1-maal (perlindungan kekayaan) tetapi juga mencegah kerusakan lingkungan sebagai realisasi dari hifdzu-n-nafsi (perlindungan kehidupan) dan hifdz-n-nasli (perlindungan keturunan) demi kehidupan manusia yang berkelanjutan.

\section{DAFTAR PUSTAKA}

Abdul Aziz, A.F., and S Mohamad. 2013. "Fulfillment of Maqasid Al-Shariah via Takaful.” In MPRA Paper, 1-25.

Abdullah, S. 2012. "Risk Management via Takaful from a Perspective of Maqasid of Shariah." Procedia-Socialand Behavioral Sciences 65: 535-41.

Akhtar, Muhammad Ramzan. 1996. "Toward Islamic Approach for Environmental Balance." Islamic Economic Studies 3(2). 
Al-Qardhawi, Yusuf. 2001. Ri'ayatu Al-Bi'ah Fi As-Syari'ah Al-Islamiyah. Cairo: Dar al-Syuruq.

Andreoni, V., and S Galmarini. 2016. "Mapping Socioeconomic Well-Being Across EU Regions.” International Journal of Social Economics 43(3): 226-43.

As-Syatibi. 1997. Al-Muwafaqat. Mesir: Daar Ibn 'Affan.

Averbeke, W. V. 2007. "Urban Farming in the Informal Settlements of Atteridgeville, Pretoria, South Africa.” AJOL African Journal Online: 338.

Bedoui, M. 2012. "Shari'a-Based Ethical Performance Measurement Framework." In The Chair of Ethics and Financial Norms in 2012,.

Butler, L, and D. M Moronek. 2002. Urban and Agriculture Communities: Opportunities for Ommon Ground, Ames. Iowa: Council for Agricultural Science and Technology.

Choudhury, M. A. 1999. "Global Megatrends and the Community." World Futures 53(2): 229-52.

DESA. 2011. World Economic and Social Survey 2011 - The Great Green Technological Transformation. New York: UN Publications.

Fauzia, I. Y. 2016. "Urgensi Implementasi Green Economy Perspektif Pendekatan Dharuriyah Dalam Maqashid Al-Shariah.” Jurnal Ekonomi dan Bisnis Islam 2(1).

Janah, Nasitotul, and Abdul Ghofur. 2018. "Maqashid As-Ayari'ah Sebagai Dasar Pengembangan Ekonomi Islam.” International Journal Ihya' 'Ulum AlDin 20(167).

Johnston, D. L. 2007. "Maqāsid Al-Sharīa Epistemology and Hermeneutics of Muslim Theologies of Human Rights." Die Welt Des Islams 47(2): 14987.

Kasri, R. A., and H. Ahmed. 2015. "Assessing Socio-Economic Development Based on Maqāsid Al-Sharīah Principles: Normative Frameworks, Methods and Implementation in Indonesia." Islamic Economic Studies 23(1): 73-100.

Kennet, M. 2008. "Green Economics - An Introduction to Progressive Economics." Harvard College Economics Review 2(1).

Khallaf, A. W. 2003. Ilmu Ushul Fikih - Kaidah Hukum Islam. Jakarta: Pustaka Amani.

Mohammed, M. O., and D.A Razak. 2008. “The Performance Measures of Islamic Banking Based on the Maqasid Framework." In IIUM 
International Accounting Conference (INTACIV),

Muhajir, A. 2015. Islam Nusantara: Ijtihad Jenius \& Ijma Ulama Indonesia Jilid 1. Jakarta: Pustaka Afid.

Negin, Vaghefi. 2017. "Building Malaysian Green Economy Model for SocioEconomic Development." International Journal of the Malay World and Civilisation (Iman): 27-32.

Rafikov, I. and Saiti, B. 2017. "An Analysis of Fnancial Speculation: From the Maqasid Al-Shari'ah Perspective.” Humanomics 33(1).

Rahma, Ali, and Makhlani. 2013. "Pembangunan Ekonomi Dalam Tinjauan Maqashid Syariah.” Researchgate.net.

Regionomica. 2012. Green Economy, Presentasi, Workshop Regional Economic Development. Jakarta: GIZBappenas.

Sahroni, O., and A. A. Karim. 2015. Maqashid Bisnis Dan Keuangan Islam Sintesis Fikih Dan Ekonomi. Jakarta: Rajagrafindo Persada.

Saumya. 2007. Green Economics, Presentation. Udai SJC.

Shihab, Q. 2003. Tafsir Al-Mishbah - Pesan, Kesan, dan Keserasian Al-Qur' an Volume 11.Jakarta: Lentera Hati.

Thomaier. 2014. "Farming in and on Urban Buildings: Present Practice and Specific Novelties of Zero-Acreage Farming (ZFarming).” Renewable Agriculture and Food Systems 30(1).

Umoh, G. S. 2006. "Resource Use Efficiency in Urban Farming: An Application of Stochastic Frontier Production Function." International Journal of Agriculture \& Biology 38.

UNEP. 2008. Reforming Energy Subsidies: Opportunities to Contribute to the Climate Change Agenda. Geneva: UNEP DTIE. 